\title{
Road and topography effects on invasion: edge effects in rat foraging patterns in two oceanic island forests (Tenerife, Canary Islands)
}

\author{
Juan D. Delgado, José R. Arévalo and José M. Fernández-Palacios
}

\begin{abstract}
Delgado, J. D., Arévalo, J. R. and Fernadez-Palacios, J. M. 2001. Road and topography effects on invasion: edge effects in rat foraging patterns in two oceanic island forests (Tenerife, Canary Islands). - Ecography 24: 539-546.
\end{abstract}

\begin{abstract}
We studied the effect of road edges on foraging activity by introduced ship or roof rats Rattus rattus in road-fragmented laurel and pine forests on Tenerife (Canary Islands). By using selective baited stations enabling only foraging by rats we assessed bait removal rates along a road-interior gradient and different topographic locations. We recorded higher removal rates in the laurel than in the pine forest regardless of the distance to road. We detected an edge effect of paved roads on introduced rat foraging. Removal rates were significantly greater along road edges than in forest interior in the laurel forest but not in the pine forest. Rats were more active along road habitats in forest ridges and slopes than in ravine beds in the laurel forest. There was no difference between topographic locations in rat activity at any distance from the road in the pine forest. It is suggested that variation in foraging intensity by introduced rats in road-fragmented forests on these islands may depend, among other factors, on forest type, road edge effects and topographic pattern of the landscape.
\end{abstract}

J.D.Delgado(jddelgar@ull.es),J.R. Arévalo and J. M. Fernandez-Palacios,Dept Ecología, Fac. de Biología, E-38206 Univ. de la Laguna, Tenerife, Islas Canarias.

A main cause of forest fragmentation in both continental and island habitats is the construction of human corridors such as road (Spellerberg 1998, Forman and Alexander 1998). Although roads are less evident at a landscape level than are massive clear-cuts, they decrease forest area and can result in the spatial isolation (insularisation) of forest remnants (Mader et al. 1990, Schonewald-Cox and Buechner 1992). At the ecosystem level, roads create artificial habitat edges that trigger many disturbance processes in time and space (Harris 1984, Arnold and Weeldenburg 1990, Bennett 1991). These effects propagate variable distances to the interior of the forest remnants depending on species and forest type (Forman and Godron 1986, Reijnen et al. 1997, Forman 1998).

One such alteration involves facilitating invasion of disturbed habitats by exotic species (Vitousek 1990, Williamson 1996). Roads can serve as conduits and habitats that are exploited by an array of habitat generalist species (Bennett 1991, Saunders et al. 1991, Rich et al. 1994, Tischendorf and Wissel 1997), and semi-isolated forest remnants divided by roads can be invaded by introduced animals (Downes et al. 1997). Many of these are opportunistic predators that severely damage the remaining habitat, often as a function of distance from the forest edge (Bennett 1991). The hypothesis that higher predation occurs along habitat edges has been tested in a variety of continental forested habitats (Forman 1998, Hartley and Hunter 1998). Here we attempt to evaluate this hypothesis in road-fragmented forests on oceanic islands where, to our knowledge, no such studies have been conducted. The relative simplicity (including paucity or absence of native predators) and fragility of island ecosystems make them prone to invasions induced by fragmentation (Whittaker 1998). Despite this, little is known

Accepted 11 January 2001

Copyright (C) ECOGRAPHY 2001

ISSN 0906-7590

Printed in Ireland - all rights reserved 
about the effects of road edges on predation by introduced species on islands.

We studied foraging patterns of introduced ship rats (Rattus rattus) in relation to forest roads on two Tenerife (Canarian archipelago) ecosystems: laurel and pine forests. These forests are colonised by rats but the extent and pattern of their effects on seed removal at forest edges have not been characterised. These forests and other Canarian ecosystems do not shelter native rodent species. By using feeding stations specifically devised for this target predator, we compared bait removal at different distances from the edges of roads in both forests. These two forests differ substantially in their structure, plant and animal species composition and abundances, but both share the same primary invading predator (ship rats). Our steering expectation was that forest invaders like rats should behave differentially in structurally different habitats in response to road edge effects and their habitat preferences. Hence, we aimed to compare patterns of road edge effects between two contrasting forests on an invader that is common at a local scale (within each forest type) and at a regional scale (between forest types) (Donovan et al. 1997).

Specifically we aimed to test these hypotheses: 1) intensity of rat foraging activity would differ between structurally contrasting forest types (Canarian laurel and pine forests); hence, the magnitude of a possible road edge effect on rat activity would be strongly dependent on forest type; 2) there is a gradient (i.e. edge effect) on rat foraging intensity between road corridor and forest interior; 3) road edge effect on rat foraging activity is affected by forest topography; this follows the previous expectations that rodent activity varies depending on forest structure (Price and Jenkins 1986, Myster and Pickett 1993, Boman and Casper 1995), and forest structure is strongly dependent on topography constraints (Ozaki and Ohsawa 1995, Miller et al. 1996).

\section{Study sites}

The study was conducted at three laurel and three pine forest stations in Tenerife. These forest landscapes form vegetation belts at different altitudes: laurel forest ranges from 600 to $1000 \mathrm{~m}$ a.s.1. on the windward slopes, and Canarian pine forest between 800 and 2000 $\mathrm{m}$ a.s.l. on both windward and leeward slopes. The laurel forest sites (Las Mercedes-Fuente de la Mina, $850 \mathrm{~m}$ a.s.1.; Monte de Aguirre, $980 \mathrm{~m}$ a.s.1., and Roque de los Pasos, $750 \mathrm{~m}$ a.s.1.) were located in the Anaga massif (NE Tenerife, $28^{\circ} 19^{\prime} \mathrm{N}, 16^{\circ} 34^{\prime} \mathrm{W}$ ). The canopy (up to $15 \mathrm{~m}$ high) was dominated by Laurus azorica, Myrica faya, Ilex canariensis, Erica arborea and Prunus lusitanica. The understory was mainly saplings of those trees, as well as Viburnum tinus and several fern species. In some forest edges and windy ridges, Erica scoparia dominated a low (3-4 m) canopy layer, along with $M$. faya and L. azorica. Two of the pine forest sites were located close to Anaga (La Esperanza, $1100 \mathrm{~m}$ a.s.1., and near Las Lagunetas, $1400 \mathrm{~m}$ a.s.1.), and the third was close to Vilaflor (SW Tenerife, $28^{\circ} 10^{\prime} \mathrm{N}, 16^{\circ} 40^{\prime} \mathrm{W}$, 1650-2000 $\mathrm{m}$ a.s.1.). The pine forest is an oligospecific community dominated by Pinus canariensis in the tree layer and by different shrub or treelet species. In the two windward slope (humid) locations, M. faya and $E$. arborea dominated a sparse understory, whereas the dominant shrubs in Vilaflor (leeward slope) are Chamaecytisus proliferus and Adenocarpus viscosus. Whereas the laurel forest sites were climatically and structurally similar, these aspects differed largely according to altitude and rainfall regimes in the pinewoods (Vilaflor being the driest site). In both laurel and pine forests, vegetation structure is clearly different between ravine beds, hill slopes and hill ridges. Tree height, diameter at breast height, and canopy cover are larger in valley bottoms, intermediate on hill slopes and lower on hill ridges. Tree density follows the inverse pattern along this topography gradient.

\section{Experimental settings}

All experiments were conducted in both forests between 31 January and 15 March 1999. We assessed rat foraging activity by offering seed baits arranged along 12 line transects per site in the laurel forest, and along 8-16 transects per site in the pine forest. A total of 36 transects were constructed per forest type (Table 1). Transects were $100 \mathrm{~m}$ in length and ran at right angles from the road edge to the forest interior, with baits situated at the following distances on each transect: $2 \mathrm{~m}$ (edge), and 20,60 and $100 \mathrm{~m}$ along the transect (Fig. 1). This transect length was chosen to avoid overlapping with the nearest roads, forest trails or cleared areas. We operated 144 baits in each forest type, with 36 replicates per distance in each forest. Transects were 10-20 m apart in each site in an attempt to minimise spatial dependence under the spatial constraints of each station. All selected road segments were roughly constant in width $(6-7 \mathrm{~m})$. Baits consisted of three whole peanuts offered on a plastic dish nailed to the ground. Position of baits in relation to topographic location

Table 1. Number of baited stations utilized in the seed removal experiment, per forest type and topographic category.

\begin{tabular}{lllll}
\hline & $\begin{array}{l}\text { Topography } \\
\text { Ravine bed }\end{array}$ & Slope & Ridge & Total \\
\hline Laurel forest & 32 & 55 & 57 & 144 \\
Pine forest & 43 & 89 & 12 & 144 \\
\hline
\end{tabular}




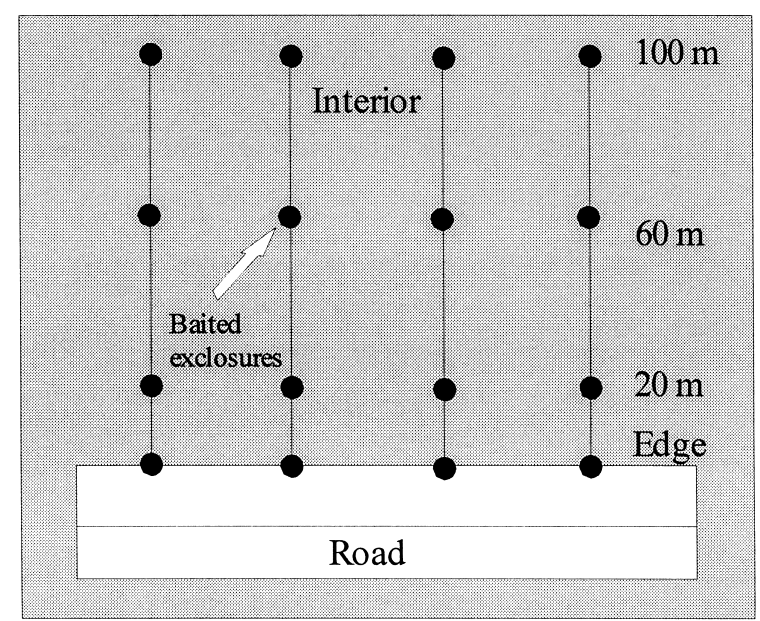

Fig. 1. Schematic setting of baited stations to study rat forag ing. Road width is not shown at the same scale (see Experimental settings for details).

(forest ridges, slopes and ravine beds) was also noted (see below). Transects evenly intercepted these landscape categories. We checked the baits after 1, 5, 15 and $30 \mathrm{~d}$. After ca $30 \mathrm{~d}$ most baits were depleted in both forests and experiments were terminated.

\section{Predator discrimination}

The ship rat has been reported as the most abundant, and frequently the only rat species for the laurel forests (González-Coloma et al. 1990, Hernández et al. 1999, Delgado 2000). The brown rat Rattus norvegicus is unlikely to be present at our sites as it mainly inhabits towns that are distant from the study areas. On preliminary assessment of the two windward pine forest sites we detected only ship rats (through road kills and eventual sightings).

Rodents are mostly nocturnal and therefore difficult to census using direct observations. In pilot experiments we detected diurnal seed consumption by the common chaffinch Fringilla coelebs. In addition, blackbird Turdus merula and Bolle's pigeon Columba bollii, and blue chaffinch Fringilla teydea and rock dove Columba livia, forage actively on the ground in the laurel and pine forests respectively (Delgado unpubl.). European rabbits Oryctolagus cuniculus are also abundant at forest edges and road limits in both laurel and pine forests. We used mesh-covered feeding stations to prevent bait consumption by these agents and thereby ensure that introduced rodents were the exclusive visitors. They were made of wire mesh $\left(1 \mathrm{~cm}^{2}\right)$ that was shaped into a semi-cylinder $(7 \times 7 \times 25 \mathrm{~cm})$ and fixed to the ground. One side was closed with a heavy stone or a tree trunk leaving a small entry hole at the opposite end.
Previous trappings in the laurel forest (Hernández et al. 1999) did not detect the only putative rodent predator apart from rats, the house mouse Mus musculus. Moreover, we did not find signs (faeces or teeth marks) that house mice used baited stations in either laurel or pine forest sites. Additional live-trappings were performed in April 2000 to confirm identity of rat species in our pine and laurel forest study sites. At each station, thirty Tomahawk live-traps baited with peanuts were arranged along $100 \mathrm{~m}$ lines at 2, 50 and $100 \mathrm{~m}$ from the roadside to the forest interior. Traps were checked each morning for 2 consecutive days and captured rats were released. Ship rat was the exclusive species captured in both forest ecosystems in all trapping sessions.

Presence of seed husks nearby the feeding stations indicated in situ consumption of baits. We considered a bait as encountered by rats when: a) at least 1 peanut was removed or consumed in situ; b) we found rat activity traces within the feeding station even in absence of bait removal. We assumed removed baits were finally consumed by rats even without finding husks nearby depleted baits.

\section{Statistical analysis}

We compared overall numbers of baits removed between forest types using a Kruskal-Wallis test. We applied survival analyses (Pyke and Thompson 1986, Fox 1993) to assess variation in rates of bait removal by rats along the road-interior gradient. This method calculates failure-time curves comparing the survivorship of baits at each time step (Willson and Whelan 1990, Fox 1993). Baits were classified as removed (presumed eaten) or not removed within the monitoring period. Those seeds surviving at the end of the experiment (i.e. those that were not removed) entered the analysis as right-censored data (data for which the real survival time is unknown) (Pyke and Thompson 1986, Fox 1993). We used this non-parametric approach because removal data were not normally distributed even after transformation, and due to the time-dependence of removal-rate data (Fox 1993). We tested the equality of survival distributions through distances to road by forest type. We also examined the effect of a gradient in topographic location of the forest on bait depletion rates. To analyse the effect of topography, we fixed the effects of road proximity and vice versa. We tested survival distributions for differences among three topographic categories: forest ridges, slopes and ravine beds. For the pinewood, we could account only for ravine and slope locations, due to the low number of ridge sites found (see Table 1). Statistical tests were performed by the Breslow $\chi^{2}$ test in the Kaplan-Meier procedure, by using the SPSS computer package (Anon. 1986). 
Table 2. Mean ( $\pm 1 \mathrm{SE}$ ) survival time (d) for bait encounter and depletion by rats in laurel and pine forests as a function of distance to the road $(\mathrm{n}=$ number of replicate baited stations per distance).

\begin{tabular}{|c|c|c|c|c|}
\hline \multirow[b]{3}{*}{ Distance to road (m) } & \multicolumn{4}{|c|}{ Survival time } \\
\hline & \multicolumn{2}{|c|}{ encounter } & \multicolumn{2}{|c|}{ depletion } \\
\hline & Laurel forest $\mathrm{n}=36$ & Pine forest $\mathrm{n}=20$ & Laurel forest $\mathrm{n}=36$ & Pine forest $\mathrm{n}=20$ \\
\hline 2 & $5.75 \pm 1.36$ & $11.50 \pm 1.74$ & $7.75 \pm 1.64$ & $10.10+1.85$ \\
\hline 20 & $6.81 \pm 1.41$ & $13.00 \pm 2.20$ & $8.25 \pm 1.63$ & $11.70 \pm 2.39$ \\
\hline 60 & $9.22 \pm 1.74$ & $17.75 \pm 2.26$ & $9.94 \pm 1.69$ & $14.00 \pm 2.11$ \\
\hline 100 & $13.92 \pm 1.96$ & $21.75 \pm 2.22$ & $14.72 \pm 1.97$ & $15.50 \pm 2.38$ \\
\hline
\end{tabular}

\section{Results}

Intensity of bait encounter and removal by rats was very high in the three laurel forest and the two windward pine forest sites, but did not occur at Vilaflor. Since this southern site probably represented an extreme situation, we will refer hereafter to data from the two remaining pine forest sites where rat foraging was evident.

There was no significant difference in the final proportion of rat-depleted baits between the laurel $(91 \%)$ and the pine $(87.5 \%)$ forests (Kruskal-Wallis $\chi_{1}^{2}=0.696$, $\mathrm{p}=0.404)$. However, pooling data over road distance, baits were found and depleted at very different rates in both forests. Baits were found significantly earlier in the laurel forest (mean days: $8.92 \pm 0.85 \mathrm{SE}$ ) than in the pine forest (mean days: $16 \pm 1.13 \mathrm{SE}$ ) (Breslow $\chi_{1}^{2}=$ 34.04, $\mathrm{p}<0.0001$ ) (Table 2). Mean bait survival time was significantly lower in the laurel forest $(10.17 \pm 0.89$ $\mathrm{SE}$ ) than in the pine forest $(12.83 \pm 1.10 \mathrm{SE}$ ) (Breslow $\left.\chi_{1}^{2}=8.58, p=0.0034\right)$. After the first day of exposure to rats, overall bait depletion was $31 \%$ in the laurel forest against only $2.8 \%$ in the pine forest.

We detected clear differences in rat foraging intensity between road edge and forest interior. For the laurel forest, both rates of bait encounter (Breslow $\chi_{3}^{2}=13.56$, $\mathrm{p}=0.0036$ ) and consumption (Breslow $\chi_{3}^{2}=10.55, \mathrm{p}=$ 0.0144 ) were significantly higher along road edges than at the interior (Fig. 2, Table 2). In the pine forest, encounter rates were higher along road edges (Breslow $\chi_{3}^{2}=10.17, p=0.0172$; Fig. 2), but consumption rates did not differ significantly between edge and interior (Breslow $\chi_{3}^{2}=3.93, \mathrm{p}=0.2686$ ) (Fig. 2, Table 2). No removal was observed until the fifth day of the experiment at pine forest interior $(60-100 \mathrm{~m})$.

The interaction between road proximity and topography influenced the pattern of rat foraging only in the laurel forest. Controlling for variation in topographic location, we found significant differences in bait removal rates between road edge and interior in the laurel forest (Breslow $\chi_{3}^{2}=15.75, \mathrm{p}=0.0013$ ), but not in the pine forest (Breslow $\chi_{3}^{2}=5.43, \mathrm{p}=0.1427$ ) (see Table 3 for pair-wise tests for the laurel forest). With road proximity fixed, we recorded highly different removal rates among sites with different topography in the laurel forest (Breslow $\chi_{2}^{2}=19.32, p=0.0001$ ), but not in the pine forest (Breslow $\chi_{1}^{2}=1.92, \mathrm{p}=0.1659$ ) (Table $3)$. In the pine forest, no pair-wise test for distances to road controlling for topography revealed significant differences (two tests with $\mathrm{p}>0.05$, and 10 with $\mathrm{p}>$ 0.1 ). Along road edges in the laurel forest, removal rates were significantly higher at slopes and ridges than at ravine beds (Table 3, Fig. 3). No significant variation in removal rates was found between laurel forest ridges and slopes, regardless of road proximity (Table 3, Fig. 3). Differences in removal rates among topographic categories decreased as distance to the edge increased $(60-100 \mathrm{~m})$ in both forests (Fig. 4, Table 3 for the laurel forest). No significant differences in predation rates between topographic categories were found beyond $60 \mathrm{~m}$ from the road in the laurel forest $(\mathrm{p}>0.05$ in every case).
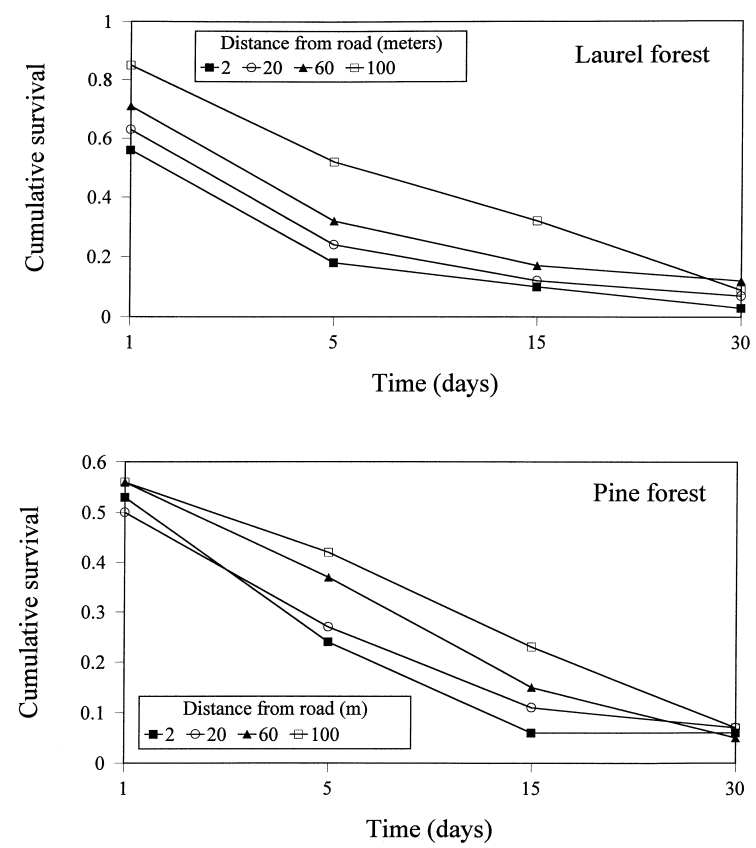

Fig. 2. Cumulative survival functions for baits consumed by rats in laurel and pine forests as a function of distance to paved roads. For estimates of the pine forest we excluded the station with zero removal (Vilaflor, see Results). Seed counts were performed at 1, 5, 15 and $30 \mathrm{~d}$ (see Results). 
Table 3. Pairwise comparisons of bait removal by rats in road corridors in the laurel forest. Only significant differences are displayed for simplicity. Figures are Breslow $\chi_{1}^{2}$ comparing pairs of distances or topographic locations, controlling sequentially for these effects (variables whose effects were fixed are shown in bold type); test probabilities: ${ }^{*} \mathrm{p}<0.05 ; * * \mathrm{p}<0.01$; $* * * \mathrm{p}<0.001$

\begin{tabular}{|c|c|c|c|c|c|c|c|}
\hline \multirow[t]{2}{*}{ Topography } & \multicolumn{4}{|c|}{ Distance to road (m) } & \multirow{2}{*}{$\begin{array}{l}\text { Distance to } \\
\text { road }\end{array}$} & \multirow{2}{*}{\multicolumn{2}{|c|}{$\begin{array}{r}\text { Topography } \\
\text { Ravine }\end{array}$}} \\
\hline & & 2 & 20 & 60 & & & \\
\hline $\begin{array}{l}\text { Slope } \\
\text { Ridge }\end{array}$ & $\begin{array}{r}100 \\
60 \\
100\end{array}$ & $\begin{array}{l}6.73^{* *} \\
9.73^{* *}\end{array}$ & $\begin{array}{c}4.29^{*} \\
4.07^{*} \\
10.10^{* *}\end{array}$ & $4.07^{*}$ & 20 & $\begin{array}{l}\text { Slope } \\
\text { Ridge } \\
\text { Slope } \\
\text { Ridge }\end{array}$ & $\begin{array}{c}7.59 * * \\
11.28^{* * *} \\
8.72 * * \\
14.39^{* *}\end{array}$ \\
\hline
\end{tabular}

\section{Discussion}

\section{Edge effects and landscape pattern: comparison between forests}

The above results revealed that: a) in terms of both rates of bait encounter and consumption, rats showed higher foraging intensity in the laurel than in the pine forest; b) there was large spatial variation in rat foraging within a given ecosystem, regarding both road proximity and topography; road edge effect upon spatial foraging pattern was more intense in the laurel forest than in the pine forest; in the laurel forest, rats found more baits than expected in the road edge, but this was not translated into edge-interior differences in bait removal; c) the interaction between road edge effect and topography affected rat foraging more obviously in the laurel forest; d) the differences in rat foraging intensity across the topographic gradient apparently decreased with increasing distance to the road border.

Highly variable predation patterns (or even absence of definite patterns) between sites or habitats frequently reflect a varying composition of predator species (Osunkoya 1994, Picman and Schriml 1994), or predator ubiquity (Matthews et al. 1999). It has been reported that both native and introduced small mammals frequently find optimal foraging conditions near road edges (Adams and Geis 1983). In other studies, native predators prefer to forage at forest interior rather than near the edges of forest remnants (Díaz et al. 1999). In an Australian forest, abundance of native rats Rattus fuscipes was higher at forest interior, whereas road edges were dominated by $R$. rattus (Downes et al. 1997). Our results showed that, though rats seem to colonize mature forest interior as well, there is a clear preference to forage near road edges.

In our study, responses of rat foraging to road proximity and topography clearly differed depending on forest type. It has been suggested that road effects may interact with the topographic component of a given forest landscape to shape the magnitude and sense of the disturbances (Miller et al. 1996). In our case, only the laurel forest exhibited significant varia- tion in rat activity across a gradient of topography. However, whereas differences between ravine bottoms and elevated sites were high, this was regardless of road proximity, and thus the road-interior gradient in rat foraging was not apparently altered by topography. The apparent lack of effect of the topography gradient upon rat activity at the forest interior may result from a decrease in rat abundance in this situation. Variation in responses to road presence for a given predator species may depend in part on the topographic landscape pattern, but also on local factors determining microhabitat preferences and hence population densities and foraging intensities (Clark 1980, Dowding and Murphy 1994, Downes et al. 1997). These questions need further research in the Canarian and other island forests.

Oceanic islands typically have simple native (if not totally exotic) predator faunas and are more likely to be damaged by exotic invaders than mainland habitats (Atkinson 1986, Coblentz 1990, D'Antonio and Dudley 1995). Such a process depends in part of the intrinsic 'resistance' of the ecosystem undergoing invasion (Williamson 1996). Our results suggest that laurel and pine forests may be differentially susceptible to the potential impacts caused by invasion of ship rats. This result may partially reflect the relative abundance or foraging intensity of rats supported by each ecosystem. Rodents vary in their pattern of selection of vegetation structure, chiefly in response to foraging costs and predator avoidance (Price and Jenkins 1986, Myster and Pickett 1993, Hovland et al. 1999). Mature pine forests are not only poorer in food resources (animals and fleshy fruits) for introduced rats than laurel forests, but also offer less protective coverage to foraging rodents due to a lower vegetation density. This was especially marked in the Vilaflor site (see Study sites). Also, the road-interior transition in vegetation structure is more dramatic in the laurel forest than in the pine forest. Selective wood extraction along road verges in the former increase vegetative shoot density that provides cover for rats against nocturnal predators. For all those reasons we may consider that the pine forest is less prone to support rat populations than the laurel forest. 
Studies identifying habitat variables related to the foraging activity of rats along road edges and forest interiors are required to predict which areas are more prone to experience the destructive effects of this introduced predator. At least in the laurel forest, predation may be heavier along road edges because of higher rat abundance. Furthermore, food availability (in the form of human garbage, native fruits and invertebrates) may be higher along road edges, influencing rat abundance and foraging intensity. Regarding topography we lack data on distribution of garbage at different topographic sites, but it is probably dependent on human accessibility to such places.
Other studies, all in continental areas, have detected edge effects on predation patterns across variable distances from road to interior (Rich et al. 1994; see review in Forman and Alexander 1998). Invading predators are known to penetrate $>1 \mathrm{~km}$ towards the interior of remnants from roads (Forman and Alexander 1998). Although, due to space constraints when establishing the transects, we detected rat foraging only up to $100 \mathrm{~m}$ from the road edge, it is likely that their ability to colonize and use deeper forest habitats goes beyond this distance. Thus, in rat-invaded Canarian forests, damaging effects upon the biota may be extended to a variable amount of area depending on
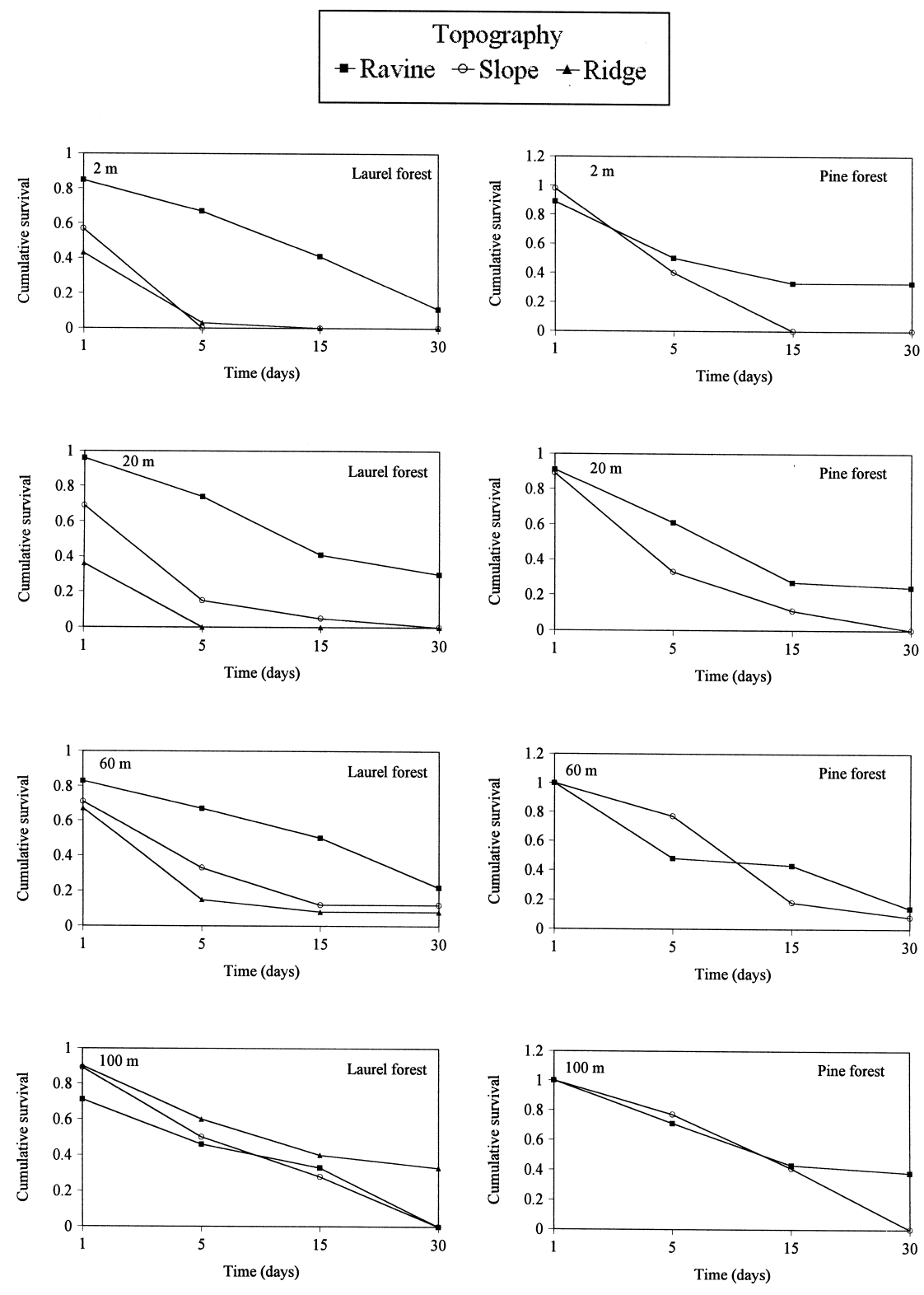

Fig. 3. Comparison of cumulative survival functions for baits in different topographic ubications in the two forests, controlling for distance to paved roads. Survival curves compare 3 topographic categories in the laurel forest and 2 in the pine forest. 
microhabitat type and road density. At a regional scale, all the above implications should be considered when: 1) assessing the global effect of roads on each ecosystem (Schonewald-Cox and Buechner 1992, Miller et al. 1996), and 2) prioritising which of these ecosystems, if any, are most in need of pest control programmes (Stone and Loope 1987). Caution is needed since we have only studied edge effects for a single season, and these patterns may vary on a seasonal or yearly basis. Analysis of this variation should be a goal of further studies. A more detailed knowledge on the type and extent of rat damage to each ecosystem, and its relation to the landscape structure and dynamics should be pursued.

Acknowledgements - We wish to thank the Viceconsejería de Medio Ambiente, Cartográfica de Canarias (GRAFCAN, S.A.) for giving us funding. Pedro Armas helped us in the field. Alfredo Valido, Sharon J. Downes and Lauren Ward made useful comments and reviewed earlier drafts. Flor E. Hernández, Yaiza Herrera, Heriberto López, Juan F. Moreno, Amagoia-Olatz Labarga, Berta Ramos, Bernardo Rodríguez, Leticia Rodríguez and Marco Rodríguez contributed with rat trapping information.

\section{References}

Adams, L. W. and Geis, A. D. 1983. Effects of roads on small mammals. - J. Appl. Ecol. 20: 403-415.

Anon. 1986. SPSS/PC + V6.0. Base manual. - SPSS, Chicago.

Arnold, G. W. and Weeldenburg, J. R. 1990. Factors determining the number and species of birds in road verges in the wheatbelt of western Australia. - Biol. Conserv. 53: $295-315$.

Atkinson, I. A. E. 1986. Rodents on New Zealand's northern offshore islands: distribution, effects and precautions against further spread. - In: Wright, A. E. and Beever, R. E. (eds), The offshore islands of northern New Zealand. New Zealand Dept of Lands and Surv. Inf. Ser. 16: $13-40$.

Bennett, A. F. 1991. Roads, roadsides and wildlife conservation: a review. - In: Saunders, D. A. and Hobbs, R. J. (eds), Nature conservation 2: the role of corridors. Surrey Beatty, Chipping Norton, Australia, pp. 99-118.

Boman, J. S. and Casper, B. B. 1995. Differential postdispersal seed predation in disturbed and intact temperate forest. Am. Midl. Nat. 134: 107-116.

Clark, D. B. 1980. Population ecology of Rattus rattus across a desert-montane forest gradient in the Galápagos Islands. - Ecology 61: 1422-1433.

Coblentz, B. E. 1990. Exotic organisms: a dilemma for conservation biology. - Conserv. Biol. 4: 261-265.

D'Antonio, C. M. and Dudley, T. L. 1995. Biological invasions as agents of change on islands versus mainlands. In: Vitousek, P. M., Loope, L. L. and Adsersen, H. (eds) Islands. Biological diversity and ecosystem function. Springer, pp. 103-121.

Delgado, J. D. 2000. Selection and treatment of fleshy fruits by the ship rat (Rattus rattus L.) in the Canarian laurel forest. - Mammalia 64: 11-18.

Díaz, I., Papic, C. and Armesto, J. J. 1999. An assessment of post-dispersal seed predation in temperate rain forest fragments in Chiloé Island, Chile. - Oikos 87: 228-238.

Donovan, T. M. et al. 1997. Variation in local-scale edge effects: mechanisms and landscape context. - Ecology 78: 2064-2075.
Dowding, J. E. and Murphy, E. C. 1994. Ecology of ship rats (Rattus rattus) in a Kauri (Agathis australis) forest in Northland, New Zealand. - N. Z. J. Ecol. 18: 19-28.

Downes, S. J., Handasyde, K. A. and Elgar, M. A. 1997. Variation in the use of corridors by introduced and native rodents in south-eastern Australia. - Biol. Conserv. 82: 379-383.

Forman, R. T. T. 1998. Land mosaics, the ecology of landscapes and regions. - Cambridge Univ. Press.

Forman, R. T. T. and Godron, M. 1986. Landscape ecology. - Wiley.

Forman, R. T. T. and Alexander, L. E. 1998. Roads and their major ecological effects. - Annu. Rev. Ecol. Syst. 29: $207-231$.

Fox, G. A. 1993. Failure-time analysis: emergence, flowering, survivorship, and other waiting times. - In: Scheiner, S. M. and Gurevitch, J. (eds), Design and analysis of ecological experiments. Chapman and Hall, pp. 253-289.

González-Coloma, A. et al. 1990. Chemical ecology of Canarian laurel forest: toxic diterpenes from Persea indica (Lauraceae). - J. Chem. Ecol. 16: 2723-2733.

Harris, L. D. 1984. The fragmented forest: island biogeography theory and the preservation of biotic diversity. - Univ. of Chicago Press.

Hartley, M. J. and Hunter, M. L. 1998. A meta-analysis of forest cover, edge effects, and artificial nest predation rates. - Conserv. Biol. 12: 465-469.

Hernández, M. A., Martín, A. and Nogales, M. 1999. Breeding success and predation on artificial nests of the endemic pigeons Bolle's laurel pigeon Columba bollii and whitetailed laurel pigeon Columba junoniae in the laurel forest of Tenerife (Canary Islands). - Ibis 141: 52-59.

Hovland, N., Andreassen, H. P. and Ims, R. A. 1999. Foraging behaviour of the root vole Microtus oeconomus in fragmented habitats. - Oecologia 121: 236-244.

Mader, H. J., Schell, C and Kornacker, P. 1990. Linear barriers to arthropod movements in the landscape. - Biol. Conserv. 54: 209-222.

Matthews, A., Dickman, C. R. and Major, R. E. 1999. The influence of fragment size and edge on nest predation in urban bushland. - Ecography 22: 349-356.

Miller, J. R. et al. 1996. Forest roads and landscape structure in the southern Rocky Mountains. - Landscape Ecol. 11: $115-127$.

Myster, R. W. and Pickett, S. T. A. 1993. Effects of litter, distance, density and vegetation patch type on postdispersal tree seed predation in old fields. - Oikos 66: 381-388.

Osunkoya, O. O. 1994. Postdispersal survivorship of north Queensland rainforest seeds and fruits: effects of forest, habitat and species. - Aust. J. Ecol. 19: 52-64.

Ozaki, K. and Ohsawa, M. 1995. Successional change of forest pattern along topographical gradients in warm-temperate mixed forests in Mt. Kiyosumi, central Japan. - Ecol. Res. 10: $223-234$

Picman, J. and Schriml, L. M. 1994. A camera study of temporal patterns of nest predation in different habitats. Willson Bull. 106: 456-465.

Price, M. V. and Jenkins, S. H. 1986. Rodents as seed consumers and dispersers. - In: Murray, D. R. (ed.), Seed dispersal. Academic Press, pp. 191-235.

Pyke, D. A. and Thompson, J. N. 1986. Statistical analysis of survival and removal rate experiments. - Ecology 67: 240-245.

Reijnen, R., Foppen, R. and Veenbaas, G. 1997. Disturbance by traffic of breeding birds: evaluation of the effect and considerations in planning and mapping road corridors. Biodiv. Conserv. 6: 567-581.

Rich, A. C., Dobkin, D. S. and Niles, L. J. 1994. Defining forest fragmentation by corridor width: the influence of narrow forest-dividing corridors on forest-nesting birds in southern New Jersey. - Conserv. Biol. 8: 1109-1121.

Saunders, D. A., Hobbs, R. J. and Margules, C. R. 1991. Biological consequences of ecosystem fragmentation: a review. - Conserv. Biol. 5: 18-32. 
Schonewald-Cox, C and Buechner, M. 1992. Park protection and public roads. - In: Fiedler, P. and Jain, S (eds), Conservation biology. Chapman and Hall, pp. $373-$ 395.

Spellerberg, I. F. 1998. Ecological effects of roads and traffic: literature review. - Global Ecol. Biogeogr. Lett. 7: 317333.

Stone, C. P. and Loope, L. L. 1987. Reducing negative effects of introduced animals on native biotas in Hawaii: what is being done, what needs doing, and the role of national parks. - Environ. Conserv. 14: 245-258.

Tischendorf, L. and Wissel, C. 1997. Corridors as conduits for small animals: attainable distances depending on move- ment pattern, boundary reaction and corridor width. Oikos 79: 603-611.

Vitousek, P. M. 1990. Biological invasion and ecosystem processes: towards an integration of population biology and ecosystem studies. - Oikos 57: 7-13.

Whittaker, R. J. 1998. Island biogeography. Ecology, evolution and conservation. - Oxford Univ. Press.

Williamson, M. 1996. Biological invasions. - Chapman and Hall.

Willson, M. F. and Whelan, C. F. 1990. Variation in postdispersal survival of vertebrate-dispersed seeds: effects of density, habitat, location, season and species. - Oikos 57: $191-198$. 
Copyright of Ecography is the property of Blackwell Publishing Limited and its content may not be copied or emailed to multiple sites or posted to a listserv without the copyright holder's express written permission. However, users may print, download, or email articles for individual use. 